\title{
Problematika Kemampuan Menyimak Mahasiswa Dalam Pembelajaran Menyimak Bahasa Arab
}

\author{
Miftahul Huda \\ Institut Agama Islam Negeri Kudus \\ miftahulhuda@iainkudus.ac.id
}

\begin{abstract}
Listening skills are a necessary requirement for understanding courses delivered in Arabic. However, not all learners of Arabic as a foreign language have good listening skills. This study aims to determine the problems faced by students, both linguistic and non-linguistic factors, in learning listening to Arabic texts. The method used in this study used a descriptive qualitative approach. As for the object as well as the source of research data are students of the PBA IAIN Kudus semester II academic year 2019/2020. Data collection was done through questionnaires, observation, interviews, and documentation. The results of the study revealed that the problems faced by students in participating in listening learning activities included difficulty remembering details and sequences of information in the text. Linguistic problems are mostly caused by a lack of vocabulary, and non-linguistic problems are caused by low motivation and interest
\end{abstract}

Keywords: listening skills, linguistics, non-linguistics, Arabic text

$$
\begin{aligned}
& \text { ملخص } \\
& \text { مهارات الاستماع هي شرط ضروري لفهم الدورات المقدمة باللغة العربية. ومع ذلك ، ليس كل }
\end{aligned}
$$

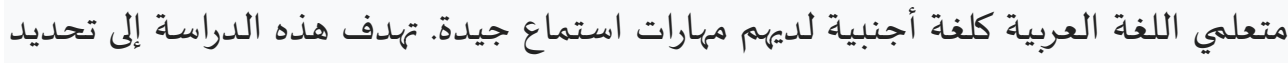

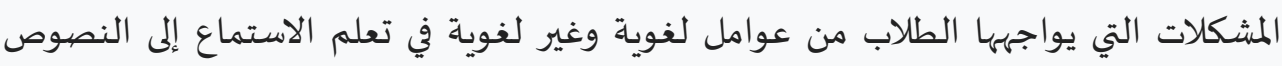

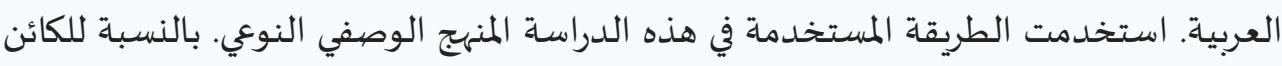

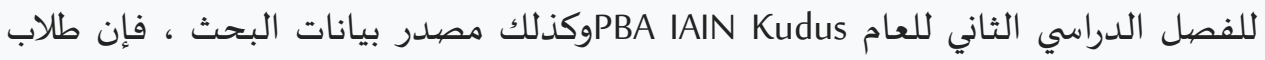

$$
\begin{aligned}
& \text { الدراسي 2020/2019. تم جمع البيانات من خلال الاستبيانات والملاحظة والمقابلات والتوثيق. }
\end{aligned}
$$




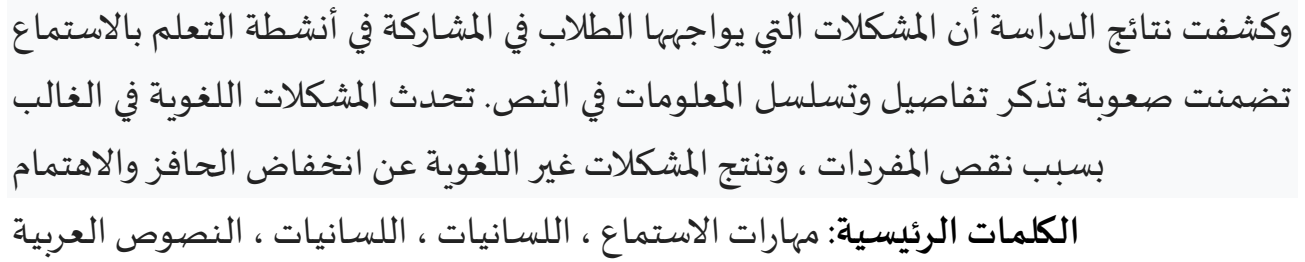

\begin{abstract}
Abstrak
Kemampuan mendengarkan merupakan persyaratan yang diperlukan untuk memahami perkuliahan yang disampaikan dalam bahasa Arab. Akan tetapi tidak semua pembelajar bahasa Arab sebagai bahasa asing memiliki kemampuan menyimak yang baik. Penelitian ini bertujuan untuk mengetahui problematika yang dihadapi mahasiswa, baik faktor lingusitik maupun nonlinguistik, dalam kegiatan pembelajaran menyimak teks bahasa Arab. Metode yang digunakan dalam penelitian ini menggunakan pendekatan kualitatif deskriptif. Adapun yang menjadi objek sekaligus sumber data penelitian adalah mahasiswa prodi PBA IAIN Kudus semester II tahun akademik 2019/2020. Pengumpulan data dilakukan melalui angket, observasi, wawancara, dan dokumentasi. Hasil penelitian mengungkapkan bahwa problematika yang dihadapi mahasiswa dalam mengikuti kegiatan pembelajaran menyimak meliputi kesulitan mengingat detail dan urutan informasi dalam teks. Adapun masalah linguistik sebagian besar disebabkan oleh kurangnya kosakata, dan masalah non-linguistik disebabkan oleh motivasi dan minat yang rendah
\end{abstract}

Kata kunci: kemampuan menyimak, linguistik, non-linguistik, teks bahasa Arab

\title{
A. Pendahuluan
}

Bahasa Arab merupakan satu disiplin ilmu yang di dalamnya terdiri dari berbagai aspek keterampilan utama. Aspek keterampilan utama tersebut meliputi keterampilan menyimak (mahārah al-istimā'), keterampilan berbicara (mahārah al-kālām), keterampilan membaca (mahārah al-qirā'ah), dan keterampilan menulis (mahārah al-kitābah) (Al-Khuli, n.d.). Keempat keterampilan tersebut saling berurutan dan saling terkait satu dengan lainnya. Dalam memperoleh keterampilan berbahasa dimulai dari belajar menyimak bahasa, lalu berbicara yang setelah itu belajar membaca dan menulis . Hal ini dibuktikan oleh fakta bahwa setiap bayi memulai memperoleh bahasa dengan mendengarkan suara di sekelilingnya, sebelum bayi tersebut mulai berbicara dan belajar membaca dan menulis 
Salah satu dari empat macam keterampilan berbahasa, yakni keterampilan menyimak. Keterampilan menyimak merupakan satu bagian penting dalam proses komunikasi, di samping sebagai dasar pembelajaran bahasa kedua (bahasa Asing). Keterampilan menyimak difahami sebagai kemampuan seseorang dalam mencerna atau memahami kata atau kalimat yang diujarkan oleh mitra bicara atau media tertentu. Bagi pembelajar bahasa asing, keterampilann menyimak merupakan keterampilan yang sangat penting. Hal ini dikarenakan keterampilan ini mutlak dibutuhkan untuk menguasai materi pelajaran dan diperlukan untuk menyimak perkuliahan yang disampaikan dengan bahasa yang bersangkutan (Tresnadewi 1994).

Seorang pembelajar bahasa asing tidak hanya dituntut untuk memahami apa yang dikatakan, tetapi juga menyeleksi bagian informasi yang penting dan relevan untuk disusun secara cepat dalam bentuk lisan maupun tulisan dan sebagai catatan yang dapat dipahami dimasa mendatang. Keterampilan menyimak dapat membantu pembelajar untuk berpartisipasi dengan baik dalam komunikasi lisan, karena komunikasi tidak bisa berhasil jika pesan yang disampaikan tidak bisa dipahami (Cahyono 1997). Hal ini dapat dipahami bahwa keberhasilan keterampilan berbicara tergantung pada keberhasilan keterampilan menyimak (Anderson\&Lynch 1988).

Menyimak merupakan suatu proses aktifitas yang lebih kompleks dari hanya sekedar mendengarkan. Mendengar merupakan satu komponen dari proses menyimak, sedangkan komponen penting lainnya adalah berpikir dan memberi makna atas apa yang didengarnya (Tompkins\&Hoskisson 1991). Mata kuliah menyimak di program studi Pendidikan Bahasa Arab IAIN Kudus adalah mata kuliah wajib prodi yang terdiri dari dua tingkat, yaitu istimā 'tamhīdī dan istimā' takmīlī. Masing-masing dari keduanya memiliki bobot 2 sks. Mata kuliah ini termasuk salah satu mata kuliah penting yang dapat menunjang mata kuliah yang lain, terutama mata kuliah yang menjadikan bahasa Arab sebagai bahasa pengantar komunikasi di dalam perkuliahan.

Namun, kondisi mahasiswa dalam mengikuti kegiatan pembelajaran menyimak saat ini masih belum maksimal. Hal ini juga dialami oleh mahasiswa prodi PBA IAIN Kudus tahun akademik 2019-2020. Beberapa problematika mendasar yang dihadapi mahasiswa dalam mengikuti proses pembelajaran menyimak adalah sebagaimana telah dikemukakan oleh (Underwood 1989) adalah (a) ketidakmampuan mengontrol kecepatan tuturan pembicara, (b) tidak adanya kesempatan mengualang tuturan, (c) keterbatasan kosa kata pembelajar, (d) 
kegagalan untuk mengenali tanda-tanda pembicara, (e) kesulitan menginterpretasikan wacana, (f) ketidakmampuan berkonsentrasi, dan (7) kebiasaan belajar.

Sementara itu Anderson\&Lynch dalam (Candlin 1991) menyebutkan ada tiga faktor utama penyebab kesulitan dalam aktifitas menyimak, yaitu: (a) bentuk bahasa, (b) tujuan menyimak, dan (c) konteks tempat menyimak dilaksanakan. Anderson\&Lynch menjelaskan bahwa kesulitan yang dihadapi dalam menyelesaikan tugas-tugas menyimak itu dipengaruhi oleh beberapa hal sebagai berikut. Pertama, Pengorganisasian informasi (teks yang disajikan secara urut kronologis akan lebih mudah dibanding dengan teks yang informasinya disajikan tidak berurutan). Kedua, pengenalan tentang topik yang disimak. Ketiga, informasi yang eksplisit dan sederhana. Keempat, bentuk ungkapan acuan yang digunakan, contoh penggunaan kata ganti akan lebih sulit dipahami daripada penggunaan kata benda secara langsung. Kelima, bagaimana teks itu dideskripsikan hubunganhubungannya (sebagai contoh dengan menggunakan gambar, bagan, dsb).

Dari pemaparan problematika di atas dan berdasarkan observasi awal serta pengalaman peneliti selama mengampu mata kuliah menyimak (istima $\bar{a}^{\prime}$ ) pada mahasiswa prodi PBA IAIN Kudus tahun akademik 2019-2020, mahasiswa banyak mengalami kesulitan. Hal itu terutama dialami oleh para mahasiswa yang berlatar belakang pendidikan dari Sekolah Menengah Atas (SMA) atau Kejuruan (SMK) yang masih memiliki pengetahuan dan dasar ilmu bahasa Arab sangat minim. Kesulitan yang dialami itu karena pada saat duduk di bangku SMA atau SMK, tidak diajarkan bahasa Arab seperti yang diajarkan secara intensif di jenjang Madrasah Aliyah (MA) maupun di pondok pesantren. Terlebih di lingkungan beberapa pondok pesantren yang mewajibkan santrinya menggunakan bahasa asing (Arab dan Inggris) dalam komunikasi sehari-hari.

Tujuan umum dari penelitian ini adalah mendeskripsikan kesulitan yang dihadapi mahasiswa dalam aktifitas pembelajaran menyimak (istimā') bahasa Arab dan problematika yang menyebabkan kesulitan tersebut. Sedangkan tujuan khusus penelitian ini adalah: (a) mendeskripsikan kesulitan yang dihadapi mahasiswa dalam mengikuti aktifitas pembelajaran menyimak (istimā') bahasa Arab, yang meliputi kesulitan dalam mengungkapkan ide pokok teks, mengingat detail dan urutan teks, memberi komentar atau penilaian terhadap teks dan membuat kesimpulan teks, dan (b) mendeskripsikan sebab-sebab kesulitan pembelajaran menyimak (istimā') yang bersumber dari aspek linguuistik dan non-linguistik. 


\section{B. Pembahasan}

\section{Kajian Tentang Keterampilan Menyimak}

\section{a. Pengertian Keterampilan Menyimak (Mahārah Istimā') Bahasa Arab}

Para ahli bahasa membedakan antara aktifitas mendengar (sima') dan menyimak (istimā'). Mendengar hanya sebatas aktifitas menerima suara tanpa adanya perhatian dan unsur kesengajaan, seperti suara kicauan burung atau suara klakson kendaraan umum di jalan. Sedangkan menyimak adalah suatu aktifitas yang menuntut adanya kesengajaan dan mendengarkan segala sesuatu yang menuntut konsentrasi serta perhatian yang lebih pada si penutur (Acep Hermawan 2011).

Keterampilan menyimak adalah kemampuan seseorang dalam mencerna kata atau kalimat yang diujarkan oleh mitra bicara atau media tertentu. Hal ini dapat dicapai dengan cara latihan secara rutin mendengarakan perbedaan bunyi unsur-unsur kata dengan unsur lainnya. Tentunya, hal itu didasarkan pada kaidah makahrijul huruf yang betul, baik dari penutur asli maupun melalui rekaman. Sebagai salah satu keterampilan reseptif, keterampilan menyimak menjadi unsur pertama yang harus terlebih dahulu dikuasai oleh pembelajar bahasa, sebelum menguasai keterampilan berbahasa lainnya.

\section{b. Tahapan Pembelajaran Materi Menyimak (Istimā') Bahasa Arab}

Secara umum, pembelajaran materi istimā' bahasa asing, khususnya bahasa Arab di Indonesia dapat disajikan dalam lima fase sebagai berikut.

1. Fase pengenalan

Pada fase ini dikenalkan bunyi-bunyi huruf Arab, baik yang tunggal maupun yang sudah digabung dengan huruf-huruf lain dalam kata-kata. Dalam hal ini seorang pengajar dituntut untuk memberikan contoh pengucapan bunyi dengan baik dan benar, kenudian diikuti oleh para siswa. Akan lebih baik jika menggunakan alat bantu kaset atau gambar-gambar tentang kata-kata yang dimaksud. Ada beberapa aspek bunyi yang sampai pada saat ini terkadang menjadi masalah dalam mempelajari bahasa Arab sebagai bahasa asing. Menurut Hasan dan Suwailih dalam Mudzakarat al-Daurat al-Tarbiyah (1986) di antara aspekaspek tersebut adalah:

a. Bunyi harakat panjang dan pendek;

b. Bunyi huruf-huruf yang sepintas mirip;

c. Bunyi huruf-huruf ber-tasydid;

d. Bunyi alif-lam syamsiyah dan qamariyah;

e. Bunyi huruf ber-tanwin; 
f. Bunyi huruf-huruf yang di-sukun-kan di akhir kata atau kalimat untuk meringankan ucapan.

2. Fase pemahaman permulaan

Pada fase ini siswa diajak untuk memahami pembicaraan sederhana yang dilontarkan oleh pengajar tanpa respon lisan, tetapi dengan perbuatan. Sebagai tahap permulaan, merespon dengan perbuatan dipandang lebih ringan dibandingkan dengan lisan.

Bentuk respon perbuatan ini dapat berupa:

a. Melakukan perintah secara fisik.

b. Bereaksi pada seruan.

c. Menjawab pertanyaan secara tertulis atau melakukan perintah dengan tulisan atau menggambar di atas kertas.

d. Melakukan perintah dengan menggunakan gambar, sketsa, denah dan sebagainya, yang sudah disediakan oleh guru. Dalam hal ini guru membagikan kertas yang di dalamnya ada gambar atau sketsa atau denah.

3. Fase pemahaman pertengahan

Pada fase ini siswa diberikan beberapa pertanyaan secara lisan atau tertulis. Sementara itu kegiatan-kegiatan yang dapat dilakukan pada fase ini adalah sebagai berikut.

a. Pengajar atau guru membacakan bacaan pendek atau memutar rekaman. Setelah itu guru memberikan pertanyaan-pertanyaan mengenai isi bacaan atau rekaman tersebut. Bentuk jawaban yang diberikan dapat berupa lisan ataupun tulisan.

b. Guru memutar rekaman percakapan dua orang penutur asli (native speaker). Selanjutnya memberikan pertanyaan mengenai isi dari rekaman tersebut. Adapun bentuk pertanyaan yang diajukan dalam poin ini lebih detail dibandingkan dengan poin pertama di atas.

c. Guru memutar rekaman percakapan seseorang, misalnya percakapan menggunakan media komunikasi seperti telefon atau whatsapp. Dalam percakapan ini yang terdengar hanya satu orang, sedangkan mitra tutur tidak terdengar. Para siswa diminta untuk mendengarkan percakapan ini dengan seksama, lalu mereka diminta untuk menebak apa yang dikatakan oleh mitra (lawan) bicara orang tersebut.

4. Fase pemahaman lanjutan

Pada fase ini siswa diberikan latihan untuk mendengarkan berita-berita dari radio, televisi atau channel youtube. Dalam kegiatan ini siswa dianjurkan untuk mendengarkan sambal membuat catatan mengenai fakta-fakta tertentu yang terjadi selama kegiatan yang terekam dalam rekaman seperti nama, tanggal, tahun, 
tempat, waktu, dan sebagainya. Hal ini dilakukan sebagai alat bantu para siswa dalam mengingat atau merekam atas apa yang sedang disimak. Setelah itu, mereka diberikan tugas untuk membuat ringkasan menggunakan bahasa Arab mengenai inti ataupun pesan yang telah disimak.

a. Menyimak siaran radio dan televisi

Menyimak siaran radio dan televisi merupakan proses menyimak yang sangat tinggi dan kompleks. Hal ini disebabkan karena siarannya yang tidak dapat diulang kembali, jika bagian pertama dari siaran tersebut terlewat, maka akan sulit merangkai dengan bagian selanjutnya.

b. Menyimak rekaman tentang kegiatan tertentu

Kegiatan menyimak dari rekaman tentang kegaitan tertentu merupakan kegiatan yang proses menyimaknya tidak serumit dari kegiatan menyimak siaran radio ataupun televise karena rekaman dapat diputar kembali.

5. Penilaian (taqwim)

Ketika fase-fase di atas sudah dilaksanakan, kemudian dilanjutkan dengan mangajukan beberapa pertanyaa yang berhubungan dengan materi istima'. Setelah itu, barulah penilaian dapat dilaksanakan. Secara garis besar penilaian dalam istima ' berhubungan dengan tujuan dan kemahiran dalam pembelajaran istima 'yang sudah disusun oleh guru ataupun pengajar bahasa Arab

\section{c. Tujuan dan Macam-macam Pembelajaran Menyimak (Istimā')}

Di antara tujuan pembelajaran menyimak (istimā') menurut Akhmad Fuad Ulyan adalah:

1. Mampu menyimak, perhatian, dan berfokus pada materi yang didengar;

2. Mampu mengikuti apa yang didengar dan menguasainya sesuai dengan tujuan menyimak;

3. Mampu memahami apa yang didengar dari ucapan penutur dengan cepat dan tepat;

4. Menanamkan kebiasaan mendengar sesuai dengan nilai sosial dan pendidikan yang sangat penting;

5. Menanamkan segi keindahan pada saat menyimak;

6. Mampu mengetahui kosakata sesuai dengan bentuk perkataan yang didengar;

7. Mampu mengetahui makna kosakata sesuai dengan bentuk perkataan yang didengar;

8. Mampu menetapkan kebijaksanaan atas perkataan yang didengar dan menetapkan keputusan yang sesuai (Abdul Wahab Rosyidi dan Mamlu'atul Ni'mah 2011). 
Ada beberapa macam jenis keterampilan istimā' menurut Akhmad Ulyan, antara lain:

1. Menyimak secara terfokus, yaitu menyimak dengan penuh kesengajaan yang dilakukan seseorang dalam kehidupannya dalam belajar dan bermasyarakat, misalnya menyimak pidato, khutbah, dsb.

2. Menyimak tidak terfokus, yaitu menyimak apa yang tersebar di sekitar kita, misalnya menyimak radio dan televisi yang dilakukan bersama dengan teman.

3. Menyimak secara bergantian, yaitu sekelompok orang yang sedang menyimak diskusi dengan judul tertentu, ada yang sedang berbicara dan yang lain mendengarkan.

4. Menyimak dengan menganalisa, yaitu menganalisa apa yang telah didengar dari penutur (Abdul Wahab Rosyidi dan Mamlu'atul Ni'mah 2011).

\section{Metode Penelitian}

Penelitian ini menggunakan penelitian kualitatif deskriptif. Peneliti hadir dalam pertemuan di kelas dalam melakukan kegaitan obsevasi proses belajar mengajar, mencatat, dan merekam. Agar dapat menemukan data yang cukup, peneliti hadir dalam pertemuan perkuliahan di kelas. Subjek penelitian yang dipilih adalah mahasiswa prodi PBA semester I peserta mata kuliah istima' tamhidi tahun akademik 2019/2020.

Data yang dikaji dalam penelitian ini adalah data mengenai problematika yang dihadapi mahasiswa dalam menyimak teks bahasa Arab dan sebab-sebab problematika tersebut. Beberapa data mengenai problematika tersebut meliputi; (a) kesulitan dalam mengungkapkan ide pokok dari teks bahasa Arab yang telah disimak, (b) kesulitan dalam mengingat detail dan urutan dari teks bahasa Arab yang telah disimak, (c) kesulitan dalam memberi komentar atau penilaian dari teks bahasa Arab yang telah disimak, dan (d) kesulitan dalam membuat kesimpulan dari teks bahasa Arab yang telah disimak. Adapun data mengenai beberapa penyebab dari kesulitan tersebut meliputi: (a) sebab kesulitan dari aspek linguistik, dan (b) sebab kesulitan dari aspek non-linguistik. Sumber data yang digunakan dalam penelitian ini adalah (a) catatan observasi, baik observasi partisipan maupun non-partisipan yang dilengkapi dengan rekaman, (b) simpulan dari hasil angket dan wawancara, dan (c) lembar jawaban tugas pekanan, ujian tengah semester dan ujian akhir semester.

Dalam penelitian ini digunakan teknik observasi, angket, wawancara dan studi dokumentasi. Observasi dilakukan untuk mengamati secara langsung subjek pada saat proses perkuliahan. Hal ini bertujuan untuk mendapatkan data tentang problematika yang dihadapi mahasiswa dalam mengikuti kegiatan menyimak. 
Angket digunakan untuk mendapatkan data mengenai sikap mahasiswa terhadap mata kuliah menyimak, kondisi mahasiswa pada saat mengikuti kegiatan menyimak, problematika yang dihadapi dan sebab-sebabnya. Wawancara dilakukan untuk memperkuat data yang telah diperoleh dari instrumen yang lain dan memperoleh jawaban secara langsung masalah sebenarnya yang dihadapi oleh mahasiswa. Dalam wawancara, peneliti hanya mengajukan pertanyaan yang terkait dengan jawaban yang telah dinyatakan pada lembar angket. Adapun studi dokumentasi digunakan untuk memperkuat data yang diperoleh melalui analisis kesalahan yang dilakukan oleh mahasiswa dalam menjawab pertanyaan dalam tugas pekanan, ujian tengah semester dan ujian akhir semester.

Langkah analisis data dalam penelitian ini dilakukan dalam beberapa tahap sebagai berikut. Pertama, transkripsi data, berupa hasil rekaman tentang proses belajar yang berisi pemutaran mp3 teks bahasa Arab, tanya jawab antara dosen dan mahasiswa serta pertanyaan-pertanyaan yang diajukan oleh dosen ditranskripsikan dan dilengkapi dengan catatan.

Kedua, organisasikan data, data yang diperoleh dari hasil observasi yang berupa transkripsi rekaman dan catatan lapangan diorganisasikan, dikelompokkan dalam empat kategori sesuai dengan rumusan masalah, yaitu data tentang kesulitan mengungkapkan ide pokok, kesulitan dalam mengingat detail dan urutan, kesulitan dalam membuat kesimpulan dari teks bahasa Arab yang telah disimak. Data yang telah terpilah dapat diketahui data mana yang telah terwakili dan belum terwakili. Data yang dianggap belum mewakili kemudian dikaji lagi melalui observasi partisipatif. Adapun data yang diperoleh melalui angket berupa problematika mahasiswa dalam menyimak digabungkan dengan data yang didapatkan melalui observasi. Sedangkan, data tentang sikap dan kondisi mahasiswadala menyimak dianalisis sebagai bahan penjelas tentang penyebab kesulitan, baik kesulitan yang bersumber dari aspek linguistik ataupun nonlinguistik.

Ketiga, kategori data, data yang diperoleh melalui wwancara dipilah dan dikategorikan pada data yang menunjang aspek kesulitan dalam mengungkapkan ide pokok teks, kesulitan dalam memberi komentar atau penilaian dari teks dan kesulitan dalam membuat kesimpulan dari teks bahasa Arab yang telah disimak. Kemudian, data tentang sebab-sebab kesulitan yang didapatkan dari hasil wawancara juga dikategorikan pada sebab kesulitan yang bersumber dari aspek linguistik dan non-linguistik. Adapun data yang diperoleh dari studi dokumentasi hasil tugas pekanan, ujian tengah semester dan ujian akhir semester dianalisis dan dikategorikan sebagai penunjang data yang telah didapatkan sebelumnya. Keempat, kesimpulan data, data yang telah dikategorikan dan diorganisasikan 
kemudian dibaca berulang-ulang dan dibandingkan dengan teori-teori yang relevan untuk disusun sebagai bahan kesimpulan penelitian.

\section{Problematika Mahasiswa dalam Menyimak Teks Bahasa Arab}

Menyimak adalah menyengaja penyampaian materi dengan pemahanan serta menguasai sebauah uraian serta akan menimbulkan gagasan darinya (Fadhil Futuhi Muhammad Wali 1990). Adapun menurut (Manna' 2000) menyimak adalah menyengaja penyampaian materi dengan pemahaman, serta menguasai sebuah uraian serta akan menimbulkan gagasan darinya. Dari kedua pemahaman tersebut dapat difahami bahwa menyimak adalah aktifitas manusia yang bertujuan pada enam hal, yaitu penguasaan, pemahaman, penjabaran, penafsiran, derivatisasi dan proses peningkatan IQ (Manna' 2000).

Oleh karena itu, keterampilan menyimak terutama menyimak bahasa asing perlu dilatih, karena proses menyimak tidak terjadi secara mekanis. Kesulitan menghadapi kosakata asing, aksen pembicara yang berbeda dengan bahasa pembelajar. Kecenderungan kata-kata tertentu, sesuai dengan yang dikehendaki pembicara, kecepatan tuturan merupakan hal-hal penyebab kesulitan menyimak.

Kegiatan menyimak sangat memerlukan konsentrasi secara penuh dan konsisten. Dalam kegiatan menyimak tidak ada kesempatan untuk mengulang atas apa yang telah disampaikan. Tidak cukup hanya memahami teks atau wacana yang disimak, akan tetapi juga menyeleksi informasi penting dan relevan untuk disusun secara cepat dalam bentuk lisan maupun tulisan.

Berdasarkan hasil penelitian yang telah dilakukan, berikut akan dipaparkan mengenai problematika yang dihadapi oleh mahasiswa, dalam hal ini dibatasi pada mahasiswa prodi PBA IAIN Kudus semester II tahun akademik 2019/2020 peserta mata kuliah istima' tamhidi, dalam mengikuti kegiatan perkuliahan menyimak teks bahasa Arab beserta sebab-sebab kesulitan yang dihadapi, baik dari aspek linguistik maupun mon-linguistik.

\section{a. Kesulitan dalam Mengingat Detail dan Urutan Teks yang Disimak}

Mengingat detail dan berurutan dari teks yang disimak merupakan kesulitan yang paling banyak dihadapi oleh mahasiswa. Mengingat detail dan urutan teks memerlukan pemahaman teks secara detail dan urut, mulai dari hal-hal atau informasi yang paling sederhana sampai pada informasi yang peling kompleks.

Kesulitan pertama yang dihadapi dalam mengingat detail dan urutan teks adalah kesulitan dalam mengungkapkan kembali dengan bahasa yang lancer dan benar. Hal ini merupakan kesulitan yang paling banyak dihadapi oleh mahasiswa. Mereka merasa kesulitan ketika harus mengungkapkan bagian-bagian detail dari teks misalnya dalam menyebutkan tanggal, bulan, dan tahun dari suatu peristiwa, menyebutkan alamat, nama telefon dan sebagainya. Mahasiswa mengungkapkan 
hal-hal tersebut dengan bahasa yang tersendat-sendat. Mahasiswa menggunakan kata $m \bar{a}: d z \bar{a}$ yang artinya 'apa' untuk memperpanjang waktu sambal mengingat-ingat apa yang akan diucapkannya. Dalam mengungkapkan detail dan urutan dari teks yang disimak dengan bahasa yang lancer dan benar mahasiswa menghadapi kesulitan dalam menggunakan kosakata, idiom, kata sambung, dan kesalahan dalam penggunaan kaidah morfologi dan sintaksis.

Kesulitan kedua adalah mengidentifikasi isi teks yang penting dan menafsirkan isi teks; dan yang terakhir adalah kesulitan dalam menghubungkan pengetahuan yang dimiliki dengan isi teks. Dalam menafsirkan isi teks mahasiswa sering terjebak dengan pengertian suatu kata sehingga menjadi salah dalam menafsirkan isi suatu teks. Untuk mengingat detail dan urutan teks yang disimak mahasiswa kadang kala tidak bisa mengingat-ingat detail dan urutan teks yang penting dalam jumlah yang banyak bila teks yang disimak itu panjang dan kosakata yang ada sulit.

Teks dalam wujud audio visual lebih menarik perhatian mahasiswa daripada teks yang dikemas dalam bentuk audio dan teks yang sudah dikenal lebih mudah dipahami daripada teks yang belum pernah dikenal oleh mahasiswa. Tingkat kesulitan teks tidak hanya ditentukan oleh penampilan teks itu sendiri, tetapi ditentukan juga oleh hubungan antara faktor teks dengan tugas-tugas yang diberikan, dan kalimat yang cakupannya lebih sempit atau dibatasi penggunaannya lebih mudah difahami.

\section{b. Kesulitan dalam Mengungkapkan Ide Pokok dari Teks yang Disimak}

Dalam mengungkapkan ide pokok dari teks yang disimak, kesulitan terbanyak yang dihadapi mahasiswa adalah dalam mengungkapkan ide pokok teks dengan bahasa yang lancar dan benar. Kesulitan ini terkait dengan aspek penguasaan kosakata, struktur kalimat, gramatika dan kaidah morfologis, terkait $i^{\prime} r a \bar{b}$, panjang pendek huruf atau aspek intonasi dan tekanan. Kemudian kesulitan dalam mengidentifikasi teks yang penting. Dalam mengidentifikasi teks yang penting mahasiswa harus memahami teks, kemudian menilai, menyeleksi dan memutuskan bagian informasi dari teks yang penting dan informasi yang tidak penting untuk dirumuskan menjadi ide pokok teks, lalu kesulitan dalam menafsirkan isi teks.

Dalam menafsirkan isi teks, mahasiswa terkadang dihadapkan pada kalimat yang bias, kabur dan bermakna ganda. Dalam menafsirkan isi teks, mahasiswa dipengaruhi oleh pemahaman terhadap teks, latar belakang yang dimiliki, serta kecerdasan dalam menafsirkan isi teks secara keseluruhan atau sebagian dari isi teks, dan terakhir kesulitan dalam menghubungkan pengetahuan yang dimiliki dengan isi teks. Hal ini merupakan kesulitan yang paling sedikit dihadapi mahasiswa dalam mengungkapkan ide pokok dari teks bahasa Arab yang disimak. 


\section{c. Kesulitan dalam Memberikan Komentar atau Penilaian Terhadap Teks yang Disimak}

Dalam memberikan komentar atau penilaian terhadap teks yang disimak, problematika yang dihadapi mayoritas mahasiswa adalah mengungkapkan kembali dengan bahasa yang lancer dan benar, serta kesulitan dalam menafsirkan isi teks kemudian kesulitan dalam menghubungkan pengetahuan yang dimiliki denga nisi teks, dan kesulitan dalam mengidentifikasi isi teks yang penting. Mahasiswa banyak mengalami kesulitan dalam menafsirkan maksud dari suatu teks, dan maksud suatu kalimat khususnya maksud atau makna dari kata-kata atau kalimat yang mempunyai makna ganda.

Kesalahan mahasiswa dalam menafsirkan isi teks yang mengakibatkan kesulitan dalam memberi komentar atau penilaian terhadap teks menyangkut pertanyaan tingkat pemahaman dan analisis. Aspek pemahaman bisa tertuju pada isi wacana, hubungan antar ide, antar faktor, antar kejadian, hubungan sebabakibat, dan sebagainya. Tingkat kesulitan pertanyaan ditentukan oleh hubungan antar pertanyaan dan jawaban. Jika hubungan bersifat langsung dan jelas, maka butir tes itu tergolong mudah. Akan tetapi, jika hubungan itu berupa kelogisan, sebab-akibat atau hubungan yang lai yang tidak langsung maka butir tes itu tergolong sulit.

Pertanyaan tingkat analisis menuntut mahasiswa melakukan analisis wacana yang didasari pemahaman terhadap wacana yang dianalisis. Analisis bias berupa analisis detail informasi, mempertimbangkan bentuk dan aspek kebahasaan tertentu, menemukan huungan kelogisan, sebab-akibat, hubungan situasional, dan lain-lain. Hal yang membedakan tes tingkat pemahaman dan analisis adalah tingkat kekompleksan wacana dan alternatif jawaban.

\section{d. Kesulitan dalam Membuat Kesimpulan dari Isi Teks yang Disimak}

Dalam membuat kesimpulan dari isi teks bahasa Arab yang disimak, problematika terbanyak yang dialami mahasiswa adalah kesulitan dalam menafisrkan isi suatu teks, kemudian kesulitan dalam mengungkapkan isi teks dengan bahasa yang lancar dan benar, dan kesulitan dalam mengidentifikasi isi teks yang penting serta kesulitan dalam menghubungkan pengetahuan yang dimiliki denga nisi teks yang disimak.

Problematika pertama adalah kesulitan dalam menafsirkan isi teks, yang merupakan aspek kesulitan terbesar yang dihadapi oleh mahasiswa. Menafsirkan isi teks merupakan suatu proses yang membutuhkan kegiatan berfikir dan memberi makna apa yang telah disimaknya. Dalam membuat kesimpulan dari isi suatu teks keterampilan menafsirkan isi teks sangat diperlukan. Apabila penyimak 
menghadapi kesulitan dalam menafsirkan isi suatu teks, penyimak akan menghadapi kesulitan dalam membuat kesimpulan dari teks yang disimak. Seperti yang telah dinyatakan (Underwood 1989) bahwa di antara masalah mendasar yang dihadapi pembelajar menyimak adalah kesulitan menginterpretasikan wacana. Sebagai contoh ketika mahasiswa diminta membuat kesimpulan dari teks yang berjudul anā wa 'äilatī mahasiswa memberikan kesimpulan yang salah terhadap deskripsi Ahmad Bashwab yang merupakan seorang pengajar mata kuliah bahasa Arab untuk non-Arab. Mahasiswa mengatakan bahwa Ahmad Bashwab seorang mengajar bahasa Arab, tanpa menyebutkan untuk non-Arab, lebih spesifik lagi untuk para pelajar yang berasal dari negara Amerika Seerikat.

Problematika kedua adalah dalam mengungkapkan kembali dengan bahasa secara lancar dan benar. Mahasiswa mengungkapkan kesimpulan dari teks yang disimak dengan bahasa yang tersendat-sendat. Beberapa kesalahan-kesalahan yang dilakukan mahasiswa dalam mengungkapkan kembali teks yang disimak dengan bahasa yang lancar dan benar adalah berupa kesalahan gramatikal, kesalahan pengucapan yang berdampak pada perubahan makna, kesalahan intonasi dan kesalahan dalam penggunaan kosakata.

Problematika ketiga adalah kesulitan dalam mengidentifikasi isi teks yang penting. Dalam mengidentifikasi isi teks yang penting mahasiswa sering terkecoh oleh isi teks yang sebenarnya hanya merupakan pendukung inti pokok dari isi teks. Hal ini menyebabkan mahasiswa membuat kesimpulan yang tidak benar. Hal-hal yang penting ditinggalkan, sementara yang tidak penting justru diungkapkan.Untuk dapat mengidentifikasi isi teks yang penting, maka dalam pemilihan materi dosen harus memperhatikan tingkat kesulitan wacana, isi dan cakupan wacana, serta jenis-jenis wacana yang digunakan. Jika kosakata yang dipergunakan sulit, bermakna ganda dan aabstrak, jarang digunakan, ditambah lagi struktur kalimatnya kompleks, wacana tersebut termasuk wacana yang tinggi tingkat kesulitannya.

Problematika keempat yangdihadapi mahasiswa dalam membuat kesimpulan isi teks adalah menghubungkan pengetahuan yang dimiliki denga nisi teks. Teks yang digunakan dosen untuk materi pembelajaran mata kuliah menyimak sebgaian besar belum dikenal oleh mahasiswa dan pengucapannya terlalu cepat. Hal ini yang menjadi salah satu faktor penyebab mahasiswa mengalami kesulitan dalam meghubungkan pengetahuan yang dimiliki denga nisi teks. Disebutkan bahwa di antara kesulitan tugastugas menyimak dipengaruhi oleh pengenalan tentang topik yang disimak (Candlin 1991). 


\section{Sebab-sebab Kesulitan yang Dihadapi Mahasiswa dalam Menyimak Teks Bahasa Arab}

Beberapa sebab kesulitan yang dihadapi oleh mahasiswa dalam kegiatan menyimak teks bahasa Arab dikaji dalam dua aspek. Pertama, sebab kesulitan yang bersumber dari aspek linguistik dan kedua sebab kesulitan yang bersumber dari aspek non-linguistik. Sebab-sebab kesulitan yang bersumber dari aspek linguistik dibatasi atas empat hal, yaitu (a) aspek kosakata, (b) aspek kekompleksan kalimat, (c) aspek kepanjangan teks, dan (d) aspek lain-lain. Adapun sebab-sebab kesulitan yang bersumber dari aspek non-linguistik dibatasi atas (a) aspek motivasi dan minta, (b) aspek metode mengajar dosen, (c) aspek media dan fasilitas pengajaran, dan (d) aspek lain-lain.

Aspek linguistik pertama yang menjadi penyebab kesulitan mahasiswa dalam mengungkapkan kembali ide pokok dari teks bahasa Arab yang telah disimak adalah faktor keterbatasan penguasaan kosakata, kalimat kompleks, teks yang panjang, diksi, kecepatan tuturan, dan kefasihan pengucapan. Kesulitan yang dihadapi mahasiswa paling banyak adalah terkait kosakata. Kesulitan yang berkaitan dengan kosakata ini bersumber dari aspek perubahan morfologis dan aspek gramatika.

Kesulitan kedua yaitu terkait dengan bentuk kalimat dari teks yang disimak. Teks yang terdiri dari kalimat yang kompleks merupakan penyebab kesulitan dala mengungkapkan ide pokok dari teks yang disimak. Kalimat kompleks menyebabkan mahasiswa mengalami kesulitan dalam menangkap pesan utama dari teks yang disimpan.

Kesulitan ketiga terkait dengan teks yang panjang. Teks yang panjang menjadikan mahasiswa jenuh dan bosan karena harus berkonsentrasi dalam waktu yang lama dan secara terus-menerus. Kesulitan keempat berupa hal-hal lain yang menjadi penyebab kesulitan dalam mengungkapkan ide pokok teks yang disimak, meliputi diksi, teks yang sulit, kecapatan tuturan dan kefasihan pengucapan.

Aspek linguistik yang menjadi penyebab kesulitan yang dihadapi mahasiswa dalam mengungkapkan detail dan urutan dari teks yang disimak adalah faktor kepanjangan teks, faktor kosakata, kalimat kompleks dan kecepatan tuturan. Teks yang panjang merupakan penyebab pertama yang kemudian diikuti penyebab lainnya. Teks yang panjang menjadikan mahasiswa sulit untuk menghafal detail dan urutan dari informasi yang terdapat pada teks yang disimak. 
Aspek kedua adalah faktor kosakata. Faktor penguasaan kosakata yang kurang, kosakata yang bermakna ganda, dan kosakata yang berasal dari bahasa 'amiyah (tidak resmi). Aspek ketiga yang dihadapi mahasiswa adalah faktor kalimat kompleks. Kalimat kompleks menjadikan mahasiswa sulit memahami teks secara utuh dan berurutan. Kalimat komplek di sini bisa berupa kalimat yang mempunyai aspek gramatikal yang rumit, memiliki unsur kalimat yang luas dan ganda. Adapun faktor keempat adalah karena kecepatan tuturan. Kecepatan tuturan menjadikan mahasiswa sulit dalam mengikuti urutan dan detail dari teks yang disimak. Kecepatan tuturan menyebabkan mahasiswa tidak mampumenampung informasi dari teks yang disimak, dan tidak adanyakesempatan untuk mengulang sesuai dengan yang dikehendaki.

Aspek linguistik yang menjadi penyebab kesulitan dala memberi komentar dan penilaian terhadap teks yang disimak adalah masalah kalimat, yaitu kalimat yang kompleks, aspek kosakata dan teks yang panjang. Kalimat kompleks, kosakata asing dan teks yang panjang menyebabkan mahasiswa merasa sulit untuk memahami teks yang disimak dan ketidakmampuan memahami teks yang disimak menyebabkan mahasiswa tidak bias memberikan komentar dan penilaian terhadap teks yang disimak.

Aspek linguistik yang menjadi penyebab kesulitan dalam membuat kesimpulan dari isi teks yang disimak adalah aspek kosakata, teks yang panjang, kalimat kompleks, aspek pemahaman dan penafsiran isi teks, dan mengungkapkan dengan bahasa yang baik dan benar. Aspek-aspek tersebut menjadi penyebab kesulitan dalam membuat kesimpulan dari teks yang disimak. Hal ini sesuai dengan pendapat Buck dalam (Robin J.\&Mendelson D.J. (eds) 1995) yang menyebutkan bahwa ada empat aspek pengetahuan penting yang harus dikuasai penyimak, yaitu (a) pengetahuan linguistik yang meliputi aspek fonologi, sistem suara, pengertian kata, sintaksis, morfologi, wacana, penanda kohesi dan lain-lain; (b) pengetahuan pendukung yang meliputi teks, seperti situasi, isi percakapan yang mendukung kemampuan memahami isi teks yang disimpan; (c) konteks bahasa yang digunakan; (d) latar belakang pengetahuan secara umum.

Aspek non-linguistik yang menjadi penyebab kesulitan dalam mengungkapkan ide pokok darit eks yang disimak adalah aspek motivasi dan minat, aspek metode mengajar, aspek takut salah, mengantuk, kurang penguasaan terhadap topik, masalah daya ingat, konsentrasi dan keseriusan, media dan fasilitas. Adapun Aspek non-linguistik yang menjadi penyebab kesulitan dalam mengingat detail dan urutan dari teks yang disimak adalah aspek motivasi dan 
minat, aspek media dan fasilitas, aspek daya ingat atau memori, kurang serius, metode mengajar, penggunaan fasilititas belum optimal.

Aspek non-linguistik yang menjadi penyebab kesulitan dalam mengungkapkan komentar dan penilaian terhadap teks yang disimak adalah aspek motivasi dan minat, keberanian berbicara, sulit memahami dan menilai isi teks, takut salah, metode mengajar, aspek media dan fasilitas mengajar. Aspek nonlinguistik yang menjadi penyebab kesulitan dalam menbuat kesimpulan dari teks yang disimak adalah aspek motivasi dan minat, takut salah, suara kurang jelas, teks kurang menarik, kemampuan terbatas, sulit memahami isi teks, metode mengajar, aspek media dan fasilitas.

Dari pemaparan di atas diketahui bahwa aspek motivasi dan minat merupakan penyebab utama kesulitan pada empat jenis problematika di atas. Hal ini menunjukkan bahwa mahasiswa kurang termotivasi terhadap mata kuliah menyimak. Minat dan motivasi mahasiswa yang kurang ini disebabkan oleh faktor ekternal, yaitu metode mengajar yang monoton dan waktu yang sangat terbatas. Adapun aspek motivasi yang disebabkan oleh faktor internal terlihat dari data mengenai sikap mahasiswa terhadap matakuliah menyimak, dan kondisi mahasiswa pada saat menyimak. Mengenai sikap mahasiswa terhaadap matakuliah menyimak diperoleh data bahwa mahasiswa mempunyai sikap yang sangat baik terhadap matakuliah menyimak. Hal itu terlihat pada sikap dalam mengkondisikan diri mereka dengan sangat baik pada waktu menyimak. Akan tetapi, mahasiswa merasa kurang termotivasi dan kurang ada minat untuk menyimak karena adanya faktor dari luar. Hal ini menyebabkan beberapa mahasiswa ada yang mengantuk, jenuh, bosan dan kurang termotivasi, terutama pada waktu siang hari.

Untuk meningkatkan motivasi dan minat dalam program pembelajaran menyimak dapat dilakukan dengan bantuan gambar, diagram, atau media lainnya yang bias digunakan untuk memvisualkan teks yang disampaikan. Di samping itu, pengajar menyimak hendaknya memanfaatkan berbagai strategi menyimak agar perhatian penyimak lebih terarah dan terfokus pada tugas-tugas yang harus dilaksanakan. Penyimak yang tidak menggunakan strategi yang sesuai akan sulit melaksanakan tugas-tugas menyimak, karena mereka tidak tahu apa yang harus dilakukannya. 


\section{Kesimpulan}

Kegiatan menyimak merupakan salah satu keterampilan berbahasa Arab yang di dalamnya terdapat beberapa problematika yang dihadapi oleh mahasiswa. Problematika atau kesulitan yang dihadapi mahasiswa terbanyak adalah kesulitan dala mengingat detail dan urutan teks yang disimak, kemudian kesulitan dalam menggunakan ide pokok, kesulitan dalam membuat kesimpulan isi teks, dan kesulitan dalam mengungkapkan komentar dan penilaian terhadap teks bahasa Arab yang disimak.

Aspek linguistik yang menjadi penyebab kesulitan terbanyak dalam menyimak adalah aspek keterbatasan kosakata, sedangkan aspek non-linguistik yang menjadi penyebab kesulitan terbanyak adalah aspek motivasi dan minat, yang disebabkan faktor eksternal, yaitu aspek metode mengajar dosen, aspek media dan fasilitas yang kurang dimanfaatkan, aspek materi yang kurang bervariasi dan aspek kesempatan yang sangat terbatas untuk berlatih kemampuan menyimak.

Berdasarkan hasil penelitian diketahui bahwa aspek linguistik yang menjadi penyebab kesulitan terbanyak dalam kegiatan menyimak adalah aspek kosakata, kalimat kompleks, dan teks yang panjang. Dengan demikian para pengajar mata kuliah menyimak hendaknya dapat memilah dan memlih teks yang disimak sesuai dengan kemampuan rata-rata mahasiswa dan memberikan penjelasan kosakata jika diperlukan.

Adapun aspek non-linguistik yang menjadi penyebab terbanyak kesulitan menyimak adalah aspek motivasi dan minat, yang disebabkan oleh faktor eksternal yang meliputi metode mengajar yang kurang bervariasi, media dan fasilitas yang kurang optimal dalam pemanfaatannya, materi yang kurang bervariasi dan kesempatan berlatih yang kurang. Karena itu hendaknya para pengajar mata kuliah menyimak untuk dapat senantiasa meningkatkan kemampuannya dalam menerapkan strategi menyimak, menggunakan berbagai media dan fasilitas pengajaran, mengemas materi dengan lebih menarik agar siswa menjadi termotivasi dan tidak cepat mengalami rras jenuh selama mengikuti kegiatan perkuliahan menyimak. 


\section{Daftar Pustaka}

Abdul Wahab Rosyidi dan Mamlu'atul Ni'mah. 2011. Memahami Konsep Dasar Bahasa Arab. Malang: UIN Maliki Press.

Acep Hermawan. 2011. Metodologi Pembelajaran Bahasa Arab. Bandung: PT. Remaja Rosdakarya.

Al-Khuli, Muhammad Ali. n.d. Asālīb Tadrīs Al-Lughah Al-'Arabiyyah. Beirut: Dar alFikr.

Anderson\&Lynch. 1988. Listening. New Tork: Oxford University Press.

Cahyono, B.Y. 1997. Pengajaran Bahasa Inggris: Teknik, Strategi Dan Hasil Penelitian. Malang: IKIP Malang.

Candlin, C.N. 1991. Language Teaching Methodology Series. New York: Prentice Hall International.

Fadhil Futuhi Muhammad Wali. 1990. Tadris Al-Lughah Al-Arabiyyah Fi AlMarhalah Al-Ibtidaiyah. Dar al-Andalus li an-Nasyr wa at-Tauzi'.

Manna', Rusydi Ahmad Thuaimah dan Muhammad as-Sayyid. 2000. Tadris AlArabiyah Fi at-Ta'lim Al-'Alam Nadhariyat Wa Tajaru. Kairo: Dar al-Fikr al'Araby.

Robin J.\&Mendelson D.J. (eds). 1995. A Guide for The Teaching of Second Language Listening. San Diego, California: Dominie Press.

Tompkins\&Hoskisson. 1991. Language Arts: Content and Teaching Strategies. New Tork: Macmillan Publishing Company.

Tresnadewi, S. 1994. "Developing Listening Skill in The EFL Classroom Guidelines.” Guidelines 16 (1): 28.

Underwood, M. 1989. Teaching Listening. London: Longman. 